\title{
Storage Stability of Vacuum Packaged Chevon Tikkis (Traditional Patties) at Refrigeration Temperature $\left(4 \pm 1^{\circ} \mathrm{C}\right)$
}

\author{
Nishant Sharma ${ }^{1 *}$, P. Prabhakaran ${ }^{2}$, Sudeep Das ${ }^{3}$ and Nidhi Bisht ${ }^{4}$ \\ ${ }^{1}$ Mobile Veterinary Unit Rudrapur (Udham Singh Nagar), Uttarakhand, India \\ ${ }^{2}$ Department of LPT, COVASc, GBPUA\&T, pantnagar, Uttarakhand, India \\ ${ }^{3}$ Department of Animal Husbandry, West Bengal Government, India \\ ${ }^{4}$ Veterinary Hospital, Thalnadi, Pauri, Uttarakhand, India \\ *Corresponding author
}

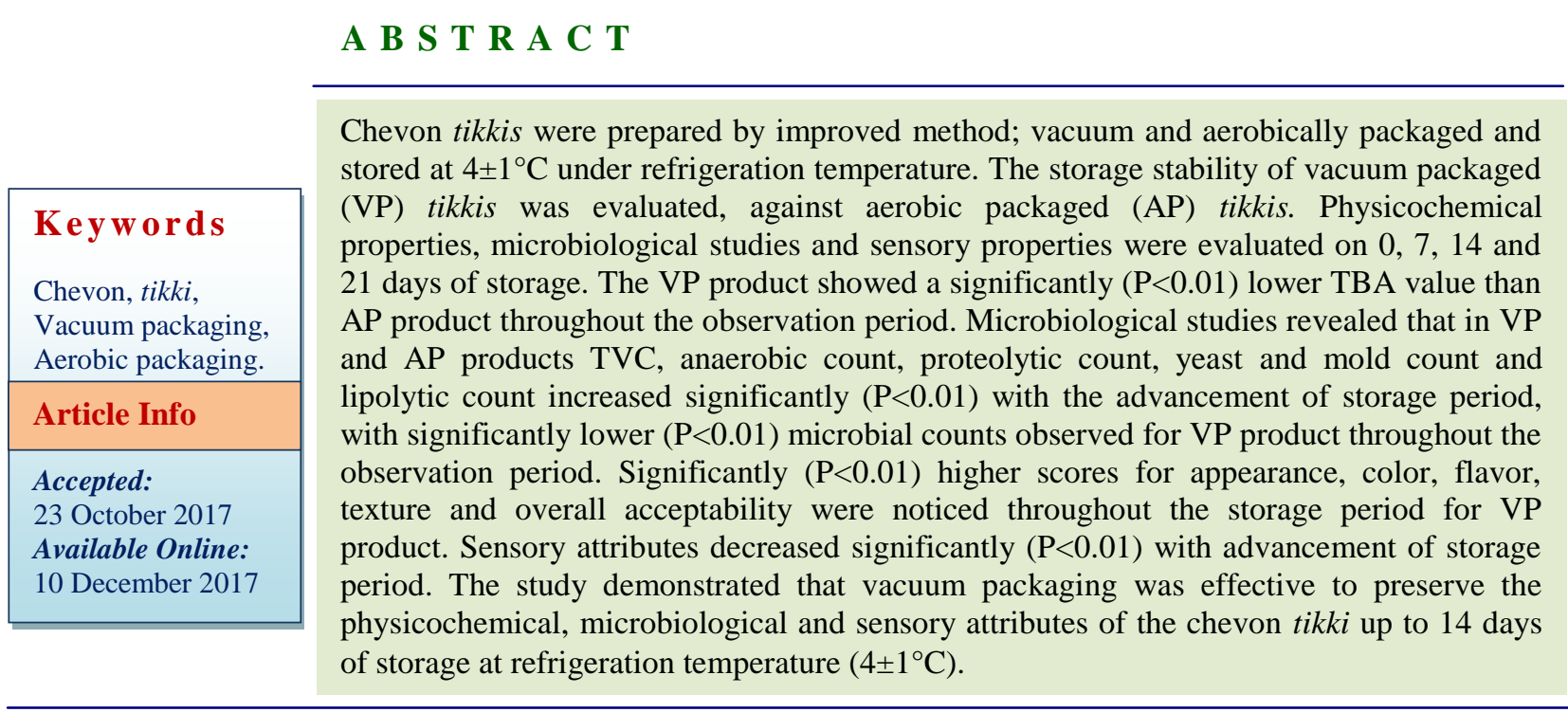

\section{Introduction}

Nearly $60 \%$ of the population of India is non vegetarian. There has been rapid growth of meat industry due to increasing affluence among the consumers. In the rapidly growing globalized world with substantively altered life style, the ready to eat, ready to cook, convenience food products are being increasingly available in the super market shelves of metropolitan cities. Indian culinary custom evolved over several thousands of years with liberal use of spices without use of chemical additives make it superior to western products (Bedeker, 2006). Market of Indian heritage food product is estimated to be around Rs. 120000 crores. But scientific studies on traditional meat products are few as compare to western meat products.

Meat is a perishable commodity and need to be properly packaged and preserved during storage and distribution. A good packaging enhances shelf life of product and increase safety. Vacuum packaging in commonly employed technology to extend shelf life of 
fresh meat and processed meat products under refrigerated storage. But studies on the effect of vacuum packaging on Indian meat products like biryani, tikka etc. are very few. Hence, the present study was proposed with objective to document the traditional methods of preparation of chevon tikkis, preparation of chevon tikkis in laboratory and to study the effect of vacuum packaging on the storage stability at refrigeration $\left(4 \pm 1^{\circ} \mathrm{C}\right)$ temperature.

\section{Materials and Methods}

All experiment was conducted in Department of Livestock Product Technology, College of Veterinary and Animal Sciences, Govind Ballabh Pant University of Agriculture and Technology, Pantnagar.

\section{Material}

Fresh boneless meat, spices, condiments, refined oil, packaging material for vacuum and aerobic packaging, table salt and other material were obtained from local market. All the chemical and media used in the study were of analytical grade and obtained from $\mathrm{Hi}$ media ${ }^{\circledR}$ Mumbai and Merck ${ }^{\circledR}$ Mumbai.

\section{Method}

\section{Documentation of chevon tikki}

A preliminary survey was conducted in the local market regarding method of preparation of chevon tikki. Based on the preliminary survey a questionnaire was prepared for personal interview with the shopkeepers around five major cities of Uttarakhand and Uttar Pradesh, viz., Rudrapur, Haldwani, Bareilly, Moradabad and Rampur.

On the basis of response a critical idea for preparation of chevon tikki was identified for adoption in the laboratory.

\section{Composition}

Boiled dal 39\%, boiled chevon 39\%, condiments $6 \% \quad(3: 1: 1: 1$ of onion: garlic: ginger: coriander), egg white $9 \%$, spices $4.5 \%$ and salt $2.5 \%$ were used.

\section{Preparation of tikki}

Boneless chevon was collected and cut into 2 inches cubes and pressure cooked for $20 \mathrm{~min}$ with water till all free water evaporated. Gram dal was boiled with water in pressure cooker for $30 \mathrm{~min}$. Equal amount of boiled dal and boiled minced meat were ground separately in meat mincer (Hobert ${ }^{\circledR}$ model 4812, USA) using $4 \mathrm{~mm}$ plate. Condiment were weighed in proportion and chopped finely. Then meat, gram dal, spices, condiments, egg white and salt were added, mixed thoroughly in to uniform dough and kept for $30 \mathrm{~min}$. The dough was then hand molded in to round shaped tikkis weighted approximately $30 \mathrm{gm}$.

\section{Packaging of tikkis}

The packaging materials were sterilized by exposing to UV light for $30 \mathrm{~min}$. A total of 32 tikkis were prepared for a trial, of which 16 were vacuum packaged in multilayer barrier bags (Zipouch $\left.{ }^{\circledR}\right)$ and rest packaged aerobically in low density poly ethylene (LDPE) bags. The packaged tikkis were stored at refrigeration temperature $\left(4 \pm 1^{\circ} \mathrm{C}\right)$.

The storage stability of vacuum packaged tikkis was evaluated on $0,7,14,21$ days of storage against aerobic packaging. For assessing the storage stability of tikkis physicochemical, microbiological and sensory evaluation was done.

\section{Physicochemical properties}

$\mathrm{pH}$ was recorded as per the procedure of Egbert et al., (1992) Water holding capacity 
(WHC) was determined by modified method of Hughes et al., (1997) as out lined by Cengiz and Gokoglu (2007). Dimensional shrinkage of tikki was determined by method of El-Magoli et al., (1996). To evaluate cooking yield tikki were weighed before and after deep frying. Then percent cooking yield was estimated by the ratio of the weight of cooked chevon tikkis to the raw chevon tikkis.

Percent cooking yield $=\frac{\text { Weight of cooked chevon patties }}{\text { Weight of raw chevon patties }} \times 100$

Thiobarbituric acid value was estimated as per procedure given by Tarladgis et al., (1960).

\section{Microbiological analysis}

Preparation of samples: Samples were prepared according to APHA (1992). Ten grams of sample was aseptically transferred to $90 \mathrm{~mL}$ of normal saline solution and serial dilutions were prepared $\left(10^{-1}\right.$ to $\left.10^{-6}\right)$.

Microbiological count: Total plate count, proteolytic count, anaerobic count, yeast and mould count and lipolytic count was determined by the method of APHA (1992), using plate count agar, molten skim milk agar, anaerobic count agar, potato dextrose agar and tributyrin agar, respectively.

Sensory evaluation: The sensory quality of samples was evaluated using 8 point descriptive scale (Keeton et al., 1984), where 8 denotes extremely desirable and 1 denotes extremely poor. A sensory panel evaluated the product for different quality attributes like, color and appearance, texture, juiciness, flavor, and overall acceptability.

Statistical analysis:-Statistical analysis was done using ANOVA technique according to the method described by Snedecor and Cochran (1989).

\section{Results and Discussion}

Documentation: Mainly three methods of chevon tikki preparation were observed in interview Minced meat and gram dal were taken in equal amount and pressure cooked boiled simultaneously in same pan

Ground meat and dal were boiled in different pan and boiled meat was also fried with onion.

Dal was boiled but ground meat was only fried with onion and then mixed with other ingredients and covered with roasted channa powder.

Along with this variation some other variants were observed

Boiling of meat with cinnamon, cassia, cardamom.

Extract of condiment used in place of condiments.

Roasted channa dal flour was used for binding in place of egg white.

Raw meat was used without boiling or frying.

Corn flour was used as binder.

Some times tikkis were enrobed by coating with beaten egg white.

The results of AP and VP chevon tikki are depicted in Table 1.

\section{Physicochemical properties}

$\mathrm{pH}-$ The $\mathrm{pH}$ of aerobic packaged tikki and vacuum packaged tikki decreased over storage period. The storage mean $\mathrm{pH}$ of AP samples decrease from $6.411 \pm 0.007$ on 0 day to $5.292 \pm 0.02$ on day 21 , while $\mathrm{pH}$ of $\mathrm{VP}$ samples decreased from 6.411 \pm 0.007 to $5.432 \pm 0.043$ on day 21. Water holding 
capacity (WHC) - No significant difference $(p>0.05)$ in the WHC was observed between treatment whereas a highly significant difference in WHC of chevon tikki was observed between storage periods. Mean WHC value of AP samples were decreased from $34.097 \pm 0.029$ on day 0 to $32.508 \pm 0.218$ on day 21 and of VP samples decreased from $34.096 \pm 0.029$ on day 0 to $33.237 \pm 0.232$ on day 21.

TBA value- Mean TBA value of AP sample was increased from $0.157 \pm 0.018$ on day 0 to $1.9994 \pm 0.040$ on day 21 . Mean TBA value of VP sample was increased from $0.157 \pm 0.018$ on day 0 to $1.1608 \pm 0.020$ on day 21 . Highly significant difference $(\mathrm{p}<0.01)$ in TBA value was observed between treatment and storage period. Cooking yield- There is no significant difference in percentage cooking yield between AP and VP samples. Mean cooking yield value of AP sample and VP sample were observed $88.754 \pm 0.770$ and $88.742 \pm 0.874$ respectively.

Dimensional shrinkage (\%) - AP chevon tikki showed mean value of percentage shrinkage $8.446 \pm 0.346$ and $8.743 \pm 0.282$ on day 0 and day 21 respectively. VP sample of chevon tikki showed mean percentage shrinkage value of $8.446 \pm 0.346$ and $10.11 \pm 0.444$ on day 0 and day 21 respectively.

Table.1 Effect of vacuum packaging on physicochemical properties, microbiological properties and sensory score of chevon tikkis stored at refrigeration temperature $4 \pm 1^{\circ} \mathrm{C}$

\begin{tabular}{|c|c|c|c|c|c|}
\hline Traits & & Oday & 7 day & 14 day & 21day \\
\hline \multirow{2}{*}{$\begin{array}{l}\text { Water holding } \\
\text { capacity }\end{array}$} & $\mathrm{AP}$ & $34.097 \pm 0.296$ & $33.595 \pm 0.406$ & $33.348 \pm 0.246$ & $32.506 \pm 0.218$ \\
\hline & VP & $34.097 \pm 0.296$ & $34.102 \pm 0.405$ & $33.796 \pm 0.327$ & $33.237 \pm 0.232$ \\
\hline \multirow[t]{2}{*}{ TBA value } & AP & $0.157 \pm 0.018$ & $0.3067 \pm 0.032$ & $0.6061 \pm 0.007$ & $1.9994 \pm 0.040$ \\
\hline & VP & $0.157 \pm 0.018$ & $0.1876 \pm 0.016$ & $0.3664 \pm 0.005$ & $1.1608 \pm 0.020$ \\
\hline \multirow[t]{2}{*}{ pH } & AP & $6.411 \pm 0.007$ & $6.063 \pm 0.087$ & $5.995 \pm 0.092$ & $5.292 \pm 0.047$ \\
\hline & VP & $6.411 \pm 0.007$ & $6.124 \pm 0.061$ & $6.086 \pm 0.053$ & $5.432 \pm 0.043$ \\
\hline \multirow[t]{2}{*}{ Cooking yield } & AP & $89.276 \pm 0.472$ & $85.563 \pm 1.556$ & $89.714 \pm 0.726$ & $90.463 \pm 0.326$ \\
\hline & VP & $89.276 \pm 0.472$ & $86.617 \pm 0.545$ & $90.793 \pm 0.383$ & $88.284 \pm 1.099$ \\
\hline \multirow{2}{*}{$\begin{array}{c}\text { Dimensional } \\
\text { shrinkage }\end{array}$} & $\mathrm{AP}$ & $8.446 \pm 0.346$ & $8.095 \pm 0.397$ & $8.708 \pm 0.414$ & $8.743 \pm 0.282$ \\
\hline & VP & $8.446 \pm 0.346$ & $8.840 \pm 0.224$ & $9.071 \pm 0.220$ & $10.11 \pm 0.444$ \\
\hline \multirow[t]{2}{*}{ TVC } & AP & $4.443 \pm 0.033$ & $6.268 \pm 0.033$ & $7.076 \pm 0.017$ & $10.722 \pm 0.124$ \\
\hline & VP & $4.443 \pm 0.033$ & $5.059 \pm 0.144$ & $5.883 \pm 0.105$ & $9.065 \pm 0.004$ \\
\hline \multirow{2}{*}{$\begin{array}{c}\text { Anaerobic } \\
\text { count }\end{array}$} & AP & $3.073 \pm 0.037$ & $3.978 \pm 0.022$ & $4.595 \pm 0.181$ & $7.868 \pm 0.166$ \\
\hline & VP & $3.073 \pm 0.037$ & $4.313 \pm 0.089$ & $4.439 \pm 0.174$ & $7.471 \pm 0.165$ \\
\hline \multirow{2}{*}{$\begin{array}{l}\text { Proteolytic } \\
\text { count }\end{array}$} & $\mathrm{AP}$ & $3.944 \pm 0.062$ & $4.096 \pm 0.168$ & $5.274 \pm 0.086$ & $7.372 \pm 0.141$ \\
\hline & VP & $3.944 \pm 0.062$ & $4.103 \pm 0.043$ & $4.739 \pm 0.134$ & $6.305 \pm 0.173$ \\
\hline \multirow{2}{*}{$\begin{array}{l}\text { Yeast and mold } \\
\text { count }\end{array}$} & AP & ND & $3.196 \pm 0.069$ & $3.485 \pm 0.205$ & $6.010 \pm 0.026$ \\
\hline & VP & ND & ND & $2.914 \pm 0.160$ & $4.802 \pm 0.024$ \\
\hline \multirow[t]{2}{*}{ Lipolytic count } & AP & ND & $3.531 \pm 0.112$ & $3.466 \pm 0.048$ & $3.819 \pm 0.170$ \\
\hline & VP & ND & $2.183 \pm 0.093$ & $1.955 \pm 0.032$ & $2.700 \pm 0.087$ \\
\hline \multirow{2}{*}{$\begin{array}{l}\text { Appearance } \\
\text { and colour }\end{array}$} & AP & $6.872 \pm 0.179$ & $4.545 \pm 0.172$ & $4.046 \pm 0.082$ & $3.500 \pm 0.101$ \\
\hline & VP & $6.872 \pm 0.179$ & $6.501 \pm 0.090$ & $5.765 \pm 0.091$ & $5.318 \pm 0.100$ \\
\hline \multirow[t]{2}{*}{ Flavor } & AP & $6.573 \pm 0.164$ & $4.457 \pm 0.139$ & $3.910 \pm 0.132$ & $3.333 \pm 0.193$ \\
\hline & VP & $6.573 \pm 0.164$ & $6.351 \pm 0.140$ & $5.877 \pm 0.095$ & $4.670 \pm 0.236$ \\
\hline \multirow[t]{2}{*}{ Texture } & AP & $6.643 \pm 0.180$ & $5.758 \pm 0.107$ & $4.595 \pm 0.139$ & $4.082 \pm 0.080$ \\
\hline & VP & $6.643 \pm 0.180$ & $6.304 \pm 0.121$ & $5.972 \pm 0.098$ & $5.193 \pm 0.153$ \\
\hline \multirow[t]{2}{*}{ Juiciness } & AP & $6.513 \pm 0.238$ & $5.128 \pm 0.154$ & $4.456 \pm 0.139$ & $3.840 \pm 0.146$ \\
\hline & VP & $6.513 \pm 0.238$ & $6.018 \pm 0.098$ & $5.642 \pm 0.072$ & $4.554 \pm 0.135$ \\
\hline \multirow{2}{*}{$\begin{array}{c}\text { Overall } \\
\text { acceptability }\end{array}$} & AP & $6.887 \pm 0.096$ & $4.497 \pm 0.111$ & $4.018 \pm 0.130$ & $3.115 \pm 0.102$ \\
\hline & VP & $6.887 \pm 0.096$ & $6.485 \pm 0.102$ & $6.004 \pm 0.058$ & $4.694 \pm 0.229$ \\
\hline
\end{tabular}

Mean \pm SE Abbreviation: AP- aerobic packaging, VP- vacuum packaging, TBA- thio barbituric acid, TVC- total Viable Count, ND- not detected 


\section{Microbiological studies}

Total viable count (TVC) - Highly significant $(p<0.01)$ difference in TVC value was observed between treatment and storage period. Mean value of TVC of AP sample was $4.443 \pm 0.033,6.268 \pm 0.033,7.076 \pm 0.017$ and $10.722 \pm 0.124$ on day $0,7,14$ and 21 respectively while VP sample showed increased value of TVC from $4.443 \pm 0.033$ on day 0 to $9.065 \pm 0.004$ on day 21 .

Anaerobic count- Anaerobic count value of AP and VP sample was increased with the storage period. AP sample showed increased mean anaerobic count value from $3.073 \pm 0.037$ on day 0 to $7.868 \pm 0.166$ on day 21. VP sample showed increased value of anaerobic count from $3.073 \pm 0.037$ on day 0 to $7.471 \pm 0.165$ on day 21 .

Proteolytic count- Both AP and VP sample showed increased value in proteolytic count over storage period. AP sample showed increased mean proteolytic count value from $3.944 \pm 0.062$ on day 0 to $7.372 \pm 0.141$ on day 21. VP sample showed increased mean proteolytic count value from $3.944 \pm 0.062$ on day 0 to $6.305 \pm 0.173$ on day 21 . Highly significant $(\mathrm{p}<0.01)$ difference in proteolytic count between treatment and between storage.

Yeast and mold count- Highly significant $(p<0.01)$ difference was observed between treatment and between storage. AP sample showed increased value of yeast and mold count from $0.000 \pm 0.000$ on day 0 to $6.010 \pm 0.026$ on day 21 while VP sample showed increased mean value of yeast and mold count from $0.000 \pm 0.000$ on day 0 to $4.802 \pm 0.024$ on day 21 .

Lipolytic count- Highly significant $(\mathrm{p}<0.01)$ difference was observed between treatment and between storage period and increased value of lipolytic count was observed over storage period. AP sample showed mean lipolytic count increased from $0.000 \pm 0.000$ on day 0 to $3.819 \pm 0.170$ on day 21 . VP sample showed mean lipolytic count increased from $0.000 \pm 0.000$ on day 0 to $2.700 \pm 0.087$ on day 21.

\section{Sensory attribute}

Appearance and colour- The overall appearance and colour score of AP and VP samples decreased over storage period. The AP sample showed a mean appearance and colour score decreased from $6.872 \pm 0.179$ on day 0 to $3.500 \pm 0.101$ on day 21 and VP sample showed mean appearance and colour score decreased from $6.872 \pm 0.179$ on day0 to $5.318 \pm 0.100$ on day 21 . There is a highly significant difference $(\mathrm{p}<0.01)$ in appearance and colour score between treatment, between storage period and interaction between treatment and storage.

Flavor- AP sample and VP sample showed a mean flavor score decreased from6.573 \pm 0.164 on day 0 to $3.333 \pm 0.193$ on day 21 and $4.670 \pm 0.236$ on day 21 respectively. Highly significant difference $(\mathrm{p}<0.01)$ in flavor score between treatment, between storage period and interaction between treatment and storage.

Texture- Mean texture score of AP and VP samples decreased over storage period. The AP sample showed a mean texture score decreased from $6.643 \pm 0.180$ on day 0 to $4.082 \pm 0.080$ on day 21 . VP sample showed decreased mean texture score from $6.643 \pm 0.180$ on day 0 to $5.193 \pm 0.153$ on day 21 . Highly significant difference $(p<0.01)$ in mean texture score between treatment, between storage period and interaction between treatment and storage.

Juiciness- Mean juiciness score of AP and VP sample was decreased over the storage period. 
AP sample showed decreased mean juiciness score from $6.513 \pm 0.238$ on day0 to $3.840 \pm 0.146$ on day 21 . VP sample showed decreased mean juiciness score from $6.513 \pm 0.238$ on day 0 to $4.554 \pm 0.135$ on day 21 . Highly significant difference $(\mathrm{p}<0.01)$ in mean juiciness score between treatment, between storage period and interaction between treatment and storage.

Overall acceptability- Mean overall acceptability score of AP and VP samples decreased over storage period. AP sample showed decreased mean overall acceptability score from $6.887 \pm 0.096$ on day 0 to $3.115 \pm 0.102$ on day21. VP sample showed decreased mean overall acceptability score from $6.887 \pm 0.096$ on day 0 to $4.694 \pm 0.229$ on day 21 . Highly significant difference $(p<0.01)$ in mean overall acceptability score between treatment, between storage period and interaction between treatment and storage.

The chevon tikkis were also known as Shami Kabab it the local market. The price of tikki varies from Rs.6-20 based on the size and standard of shop. Weight of tikkis varies from 20-35 gm. Survey revealed that there are three method of chevon tikki preparation. Coarsely chopped chevon was used for making tikkis. Incorporation of Bangal dal in making tikkis leads to better cooking yield because of its adhesive and thickening quality (Biswas and Kesari 2003). Soaked dal was used, as boiling of soaked dal take lesser time then unsoaked dal (Willium and Singh 1987). Pressure cooking of dal and meat together saved time and energy of cooking. Respondents also stated that complete evaporation of water in pan used for chevon boiling leads to better flavor and binding ability. Most respondents stated that incorporation of egg white in product resulted in better binding and increased sensory score due to its albumin content and emulsifying capacity (Randall et al., 1984). As most of the product were sold on same day so preservation of product is rare but due to change in socio-economic condition in society and for better commercialization and marketing the product need to be stored for longer period. Hygiene is directly related with the microbial quality of product. In the present study the product was prepared under hygienic conditions and with the use of machineries. Using of machineries under hygienic condition help to reduce cost of product, quality of product and improve self-life also.

\section{Physicochemical properties}

$\mathrm{pH}$ value of AP tikki showed lower value then compare to VP tikki. No significant effect was observed in interaction between treatment and storage period on $\mathrm{pH}$ of chevon tikki. These findings are in agreement with Babji et al., (2000). WHC of AP tikki and VP tikki showed non-significant difference between treatment while WHC value of AP and VP tikki decreased over the storage period. Lin and Lin (2002) also reported decreased WHC of sausages at refrigeration after two week of storage. Naveen et al., (2015) reported improved WHC of AP and VP emu meat over storage period. VP chevon tikki showed significantly lower TBA value when compare to AP chevon tikki. TBA value of VP tikki was marginally higher then acceptable level on 21 day of storage. In case of AP tikki TBA value were very high. TBA value increased significantly $(\mathrm{p}<0.01)$ with advancement of storage. Bhattacharyya et al., (2013) observed increased trend in TBA value of duck sausages with the storage period under refrigeration. These results are in agreement with Rajkumar et al., (2004), Maca et al., (1997) and Lin and Lin (2002).

\section{Microbiological properties}

Total value count of VP tikki showed significantly lower value then AP tikki over 
the period. AP tikki had higher value of TVC then acceptable level on 7 day of storage. However VP tikki showed TVC well within acceptable level on 14 day of storage. Bhattacharyya et al., (2013) found increased trend in yeast and mold count of duck sausages with storage period under refrigeration storage $4 \pm 1^{\circ} \mathrm{C}$. These finding are in agreement with Dharamveer (2007), Rajkumar et al., (2004), Pawankumar et al., (2003), and Maca et al., (1997). Anaerobic count of AP and VP tikki showed no significant difference. Storage mean showed significantly increasing trend in anaerobic count. These results are in agreement with Rajkumar et al., (2007). Proteolytic count of VP tikki showed significantly lower value then AP tikki. Storage mean showed significantly increasing trend in proteolytic count. These results are in agreement with Thomas et al., (1991). Yeast mold count and lipolytic count of VP tikki showed significantly lower value then AP tikki. Storage mean showed significantly increasing trend in yeast mold count and lipolytic count. Bhattacharyya et al., (2013) found increased trend in yeast and mold count of duck sausages with storage period under refrigeration storage $4 \pm 1^{\circ} \mathrm{C}$. These results are in agreement with Dharamveer et al., 2007, Babji et al., (2000), Rajkumar et al., (2004), Havas (1990) and Igbinedion (1981).

\section{Sensory evaluation}

Vacuum packaged chevon tikki showed significantly higher sensory score when compare with AP tikki. Storage mean showed significantly decreasing trend in sensory attributes of chevon tikki. Interaction between treatments and storage periods showed a significant difference in sensory score of chevon tikki. Highest sensory score was observed on day 0 and lowest on day 21 . These results are in agreement with Rajkumar et al., (2004) and Dharamveer et al., (2007).
Bhattacharyya et al., (2013) observed decreased in sensory score of duck sausages with increase in storage period at refrigeration temperature.

The study demonstrated that the physicochemical, microbiological and sensory quality of vacuum packaged chevon tikkis was better than aerobic packaged tikkis. Aerobically packaged tikkis have unacceptable level of microbial count and sensory score on day 7 while vacuum packaged tikkis have unacceptable level of microbial count and sensory score on day 21 . Therefore chevon tikki can be preserved at refrigeration temperature $4 \pm 1^{\circ} \mathrm{C}$ for 14 day under vacuum packaging with acceptable physicochemical, microbiological and sensory score.

\section{Acknowledgement}

I am thankful to College of Veterinary and Animal Sciences, the Department of LPT, GBPUAT, Pantnagar, Uttarakhand for providing necessary facilities to conduct the experiments.

\section{References}

APHA, 1992. Compendium of Methods for the Microbiological Examination of Foods. $2^{\text {nd }}$ edn. (ed. M.L. Speak). American Public Health Association, Willbehington, D.C.

Babji, Y., Murthy, T.R.K. and Anjaneyulu, A.S.R. 2000. Microbial and sensory quality changes in refrigerated minced goat meat stored under vacuum and in air. Small Ruminant Research. 36: 7584

Bedekar, B.R. 2006. Heritage or Traditional Processed Food- Where is the Technology. Indian Food Industry. 25(6): 46-47

Bhattacharyya, B.A., Sinhamahapatra, M. and 
Biswas, S. 2013. Effects of Packaging Materials and Methods on Physical Properties and Food Safety of Duck Sausage. International Journal of Development Research. 3: 32-40.

Biswas, A.K. and Kesari, R.C. 2003. Incorporation of Bengal Gram flour in development of pork patties. Journal of Veterinary Public Health 1(1): 75-80

Cengiz, E. and Gokoglu, N. 2007. Effects of fat reduction and fat replacer addition on some quality characteristics of frankfurter-type sausages. International Journal of food science and Technology. 42: 366-372

Dharamveer, S., Rajkumar, V. and Mukesh, K.P. 2007. Quality and shelf life of smoked chevon sausages packed under vacuum and stored at $4 \pm^{\circ} \mathrm{C}$. American Journal of food Technology. 2(4): 238247

Egbert, W.R., Huffman, D.L., Chen, C.M. and Jones, W.R. 1992. Microbial and oxidative changes in low fat ground beef during simulated retail distribution. Journal of Food Science. 57(6): 12691274

El-Magoli, S.B., Laroria, S. and Hansen, P.M.T. 1996. Flavour and texture characteristics of low-fat ground beef patties formulated with whey protein concentrate. Meat Science. 42: 179-193

Havas, F. 1990. Study on judgement of the expiry (shelf life) of cured, smoked, sliced and vacuum-packed back-bacon. Magyar Allatorbosok Lapja. 45(3): 149152

Hughes, E., Cofrades, S. and Troy, D.J. 1997. Effects of fat level, oat fibre and carrageenan on frankfurters formulated with 5, 12 and 20\% fat. Meat Science. 45: $273-281$

Igbinedion, J.E. 1981. Effects of packaging methods, display light and time on the riboflavin retention, microbial growth, rancidity and $\mathrm{pH}$ of fresh pork stored at
$2 \pm 1{ }^{\circ} \mathrm{C}$. Dissertation Abstracts International. 41(10): 3726

Keeton, J.T., Foegeding, E.A. and Patina, A.C. 1984. A comparison of non meat products, sodium tripolyphosphate and processing temperature effects on physical and sensory properties of frankfurters. Journal of Food Science. 49(4): 1462-1474

Lin, K.W. and Lin, S.N. 2002. Physicochemical properties and microbial Stability of reduced fat Chinese-style sausage stored under modified atmosphere system. Journal of Food Science. 67(8): 3184-3188

Maca, J.V., Miller, R.K. and Acuff, G.R. 1997. Microbiological, sensory and chemical characteristics of vacuum packaged ground beef patties treated with salts of organic acids. Journal of Food Science. 62(3): 591-596.

Naveena, B.M., Muthukumar, M., Kulkarni, V.V., PraveenKumar, Y., Usha Rani, K. and Kiran, M. 2015. Effect of Aging on the Physicochemical, Textural, Microbial and Proteome Changes in Eтu (Dromaius novaehollandiae) Meat Under Different Packaging Conditions. Journal of Food Processing and Preservation. 12499

Pavankumar, K.R., Sachindra, N.M. and NarasimhaRao, D. 2003. Quality characteristics of vacuum packed tandoori chicken. Journal of Food Science and Technology. 40(3): 313315

Rajkumar, V., Agnihotri, M.K. and Sharma, N. 2004. Quality and shelf-life of vacuum and aerobic packed chevon patties under refrigeration. AsianAustralian Journal of Animal Science. 17: $548-553$

Rajkumar, V., Dushyanthan, K., AshaRajni, R. and Surenderkumar, S. 2007. Effect of modified atmosphere packaging on microbial and Physical properties of 
turkey meat. American Journal of Food Technology. 2(3): 183-189

Randall, C.J., Raymond, D.P. and Voisey, P.W. 1984. Effect of various animal and vegetable protein materials on replacing the beef component in a meat emulsion system. Canadian Institute of Food Science and Technology Journal. 9: 216-221

Snedecor, G.W. and Cochran, W.G. 1989. Statistical Methods, $8^{\text {th }}$ ed. Ames, Iowa State University Press.

Tarladgis, B.G., Watts, B.M., Younathan, M.T. and Dugan, L.R. 1960. A distillation method for the quantitative determination of malonaldehyde in rancid foods. Journal of American Oil Chemistry Society. 37: 44-48

Thomas, A.H., Kaysner, C.A., Colburn, K.G., Sullivan, J.J., Abeyta, C., Walker, K.D., Torkelson, J.D., Throm, H.R. and Wekell, M.M. 1991. Chemical and microbiological analysis of vacuum packed, pasteurized flaked imitation crab meat. Journal of Food Science. 56(1): 164-167

Willium, P.C. and Singh, U. 1987. Nutritional quality and the evaluation of quality in breeding programme. In: The Chickpea. AB Publication. Pp. 339-357

\section{How to cite this article:}

Nishant Sharma, P. Prabhakaran, Sudeep Das and Nidhi Bisht. 2017. Storage Stability of Vacuum Packaged Chevon Tikkis (Traditional Patties) at Refrigeration Temperature $\left(4 \pm 1^{\circ} \mathrm{C}\right)$. Int.J.Curr.Microbiol.App.Sci. 6(12): 3134-3142. doi: https://doi.org/10.20546/ijcmas.2017.612.365 